\title{
Economic History and History of Economics: Complementary Approaches to Portuguese Economic Development
}

\author{
José Luís Cardoso
}

\begin{abstract}
This chapter focuses on how the problems of economic development were addressed by the Portuguese historiography of the late nineteenth and twentieth centuries. The ensuing discussion benefits from the simultaneous consideration of two historiographical domains that complement each other: economic history and the history of economics. On the one hand, there are the authors and texts of economic history that seek to describe the facts and circumstances related to the functioning and dynamics of economic reality, for a given period or succession of periods, in order to establish evolutionary trends. On the other hand, there are the authors and texts of the history of economics that seek to adopt analytical forms (principles and laws) and doctrinal and programmatic frameworks (visions and ideologies) aimed at providing explanatory meaning to the observed economic changes, phenomena and regularities. A true understanding of the important issues pertaining to Portuguese economic development is to be found, however, in the intersection of these distinct but complementary historiographical perspectives.
\end{abstract}

Keywords Economic development $\cdot$ Economic history $\cdot$ History of economics • Methodology $\cdot$ Portugal

\section{Introduction}

The title of this contribution refers to an important methodological issue when studying the problems of Portuguese economic development: the simultaneous application of two complementary historiographical domains, namely economic history and history of economics. ${ }^{1}$ These approaches are sometimes erroneously presented

\footnotetext{
${ }^{1}$ The present contribution is largely based on the duly authorized translation of a chapter written in Portuguese, namely (Cardoso 2017), which is included in a book of limited circulation within academic circles.
}

J. L. Cardoso (凶)

Instituto de Ciências Sociais, Universidade de Lisboa, Lisbon, Portugal

e-mail: jcardoso@ics.ulisboa.pt 
as one and the same, and sometimes also wrongly claimed to be autonomous from one another.

Indeed, the historical memory brings different and seemingly appropriate words to the discussion of the developmental problems of the Portuguese economy and society throughout the period being considered here (the early 1870 s to the early 1970s). In the lexicon of concepts, words such as modernization, improvements, advances, regeneration, promotion and progress are often used to express the dynamic movement of structures that support, and project into the future, a sense of collective purpose, i.e., words that convey the notion that things change even when everything seems to remain as before.

Other form of expressions referring to the constraints that hinder the processes of change and modernization is also frequently used. The discussion on this matter essentially leads to the naming of physical and moral causes of economic backwardness (i.e., the circumstances and factors of a natural or political nature) or simply the explanatory reasons for economic decline.

To be sure, we observe a certain degree of continuity and persistence in the use of these concepts and expressions throughout the period under consideration. The reason is that these are recognized to be useful as diagnostic tools, as well as a blueprint of the strategic orientations to be pursued in the future. This is evident, for example, in the writings of the Royal Academy of Sciences of Lisbon during the late eighteenth century regarding improvements to be implemented in different sectors of economic life and also in the 1960s writings on developmental issues which called for a break with the Estado Novo growth model. ${ }^{2}$ The recurrent use of these expressions reveals the potentialities and virtues of inquiring into the conditions and factors that contribute toward Portuguese economic and social development.

Now, the discussion employing expressions such as expansion and decay, progress and backwardness and improvements and obstacles has always been present in the Portuguese economic literature since the dawn of the mercantilist era. In methodological terms, this discussion relied on two distinct disciplinary approaches even though neither claimed complete autonomy. On the one hand, some authors and studies sought to describe the facts and circumstances of relevance to the functioning and dynamics of economic phenomena (such as consumption, production, population growth, currency, credit, taxes) for a given period or a succession of periods. These studies thus sought to distil evolutionary trends from observable facts. On the other hand, other authors and studies focused on the analytical forms (principles and laws) and doctrinal and programmatic frameworks (visions and ideologies) that gave explanatory meaning to both the observed regularities and the changes in economic facts or phenomena.

These two distinct approaches, respectively, bring us to the historiographical fields of economic history and the history of economic science and ideas (or more succinctly, the history of economics), which nowadays have well-identified lineages and historiographical sequences.

\footnotetext{
${ }^{2}$ The Estado Novo (New State) refers to the authoritarian, corporatist and statist period of rule in Portugal during 1933-1974.
} 
Given that these two disciplinary fields initially appeared as only one (as it was difficult to separate the history of economic facts from the history of interpreting these facts), there is no point in strictly separating them, however. This is especially true because the authors who most advanced knowledge in the two domains, which we now consider to be autonomous, were often one and the same. Examples of this disciplinary ambivalence are evident in the works of authors such as José Frederico Laranjo, António Sérgio, Moses Amzalak, Armando Castro, Virgínia Rau, Vitorino Magalhães Godinho and Jorge Borges de Macedo. In other words, these authors had the double facet of being both historians of economic facts and historians of economic ideas. In Sect. 5 below, the discussion's focus will be on the contributions of Magalhães Godinho and Borges de Macedo, given their proximity to contemporary historiography.

\section{The First Steps Toward Economic History Scholarship}

In any historiographical review focused on Portugal, it is easy to understand what leads us to recall the pioneering contribution of Alexandre Herculano. When it comes to economic historiography, the inevitable recollection of his name is not due to his heuristic ambition of systematically tackling the intellectual territory where economic and financial facts and themes are displayed and discussed. Above all else, the relevance of Herculano's contribution stems from the way in which he used and adapted the influences of German historicism in search of a narrative about the "nature of societies," as opposed to one built upon the deeds and shadows of heroes. The readers of his works were able to analyze and evaluate the importance and weight of institutions, economic structures and problems, especially in some of his Opúsculos, which included economic considerations on the feudal and seigneurial regime, the land property regime of the church, crown and nobility and also savings banks and mutual aid insurance systems in Portugal (Herculano 1873).

Oliveira Martins is another noteworthy figure of nineteenth-century Portuguese historiography. His historical incursions were mostly focused on specific economic and financial problems, which were addressed using an analytical framework and a short-term pragmatic perspective, for the study of economic reality (Martins 1872, 1883). Regarding the latter, he sought to propose solutions for concrete problems that he felt should not be overlooked, given both his interventionist and publicist vein and his eagerness to take on a reformist political responsibility (Martins 1885). In fact, Oliveira Martins' attributes of being a public intellectual and politician led him to focus especially on economic and financial matters.

At the theoretical level, Oliveira Martins was influenced by, and particularly receptive to, the contributions of the then current school of thought known as "socialism of the chair (catedra)" and also by the German historical school from which he inherited a critical sense regarding the supposed universality of abstract laws in political economy. In his view, such universality was either unattainable or would lead to the adoption of economic developmental concepts that did not properly value the 
effort needed to create conditions for the full allocation of national resources. At the political level, these same influences highlighted the need for national development strategies that were adapted to the historical and geographical specificities of the economic reality under study, which could then be marshaled into a project of change.

According to Oliveira Martins, the reliance on history to study economic reality was a source of learning aimed at affecting the present time, enabling the construction of explanatory interpretations as to the country's economic backwardness in relation to the observed pace of progress in most developed nations. It could also help with the design of proposals that would improve, regenerate and promote various sectors of economic activity, especially agriculture. Historical reflection on economic issues (or even only historical exemplification) was understood to be a form of political and civic intervention needed to create an opportunity for the country to overcome its long cycle of economic decline. This view, which was not always supported by irrefutable proof or historical evidence, would later have repercussions in the historiographical work of authors such as Cortesão (1930) and Sérgio (1924), who were greatly influenced by Oliveira Martins. In general terms, this view also served to consolidate a pessimistic tradition regarding the country's real economic potential, which has since been accepted and echoed in the public imagination.

The names of João Manuel Esteves Pereira and Basílio Teles also deserve to be singled out among the politicians and historians that were contemporaries of Oliveira Martins. They too contributed to the creation of a historiographical canon dealing with economic issues in the late nineteenth and early twentieth centuries. The former historian is best known due to his two studies on the Portuguese industry's history, which were published in the Ocidente journal in 1897 and 1900 (collected in Pereira 1979), and the latter due to his historical essays on work organization, agriculture, credit and taxation systems (Teles 1901).

The political economy textbooks used at the University of Coimbra should also be mentioned, namely those of José Frederico Laranjo and, especially, Marnoco e Sousa. Both authors made slight incursions into economic history and always through the influence of political economy-historical schools that sought to contextualize the application of laws and principles, which were supposedly valid for any given country and time (Laranjo 1891; Sousa 1910). The works of these authors also include side reflections on the evolutionary process of economic ideas, leading to the emergence of autonomous studies in the field of the history of economic thought (Laranjo 1881-1884).

A very special mention is also due to Alberto Sampaio for his concise interpretation of historical exercises entailing a high level of abstraction. His monographic studies on the economic habits and customs of the populations in northern Portugal reveal quite well the methodological accuracy of his thinking:

It is superfluous to stress the importance of the issues being broached in this work; the author believes, however, that few readers who will enjoy a story without characters, and lacking the appeal that arises from the drama of passions and the play of interests; however, the reader will be satisfied should the experts deem the story to bring any value, however small, to knowledge about the origins; should an outline also result from the elements that the author 
collects regarding the establishment of property and agricultural systems in the north of the country, even if only it be a rough one; and finally, if in this manner, should one be able to slightly extend one's historical horizon. (Sampaio 1923 [1899], pp 5-6)

While succinct, this reflection undoubtedly accords Alberto Sampaio a role as a forerunner when it comes to identifying the benchmarks to which economic history should measure itself.

\section{In Search of the Systematization of a New Disciplinary Field}

During the first three decades of the twentieth century, the Portuguese editorial scene witnessed the publication of the first works that identified, in their very titles, a new discipline with historical scope, namely economic history.

Adriano Antero's voluminous compendium is such a case in point. This work comprises long tracts on the history of economic life in ancient Greece and Rome, which also reveal his ultra-descriptive, ultra-factual and semi-geographical view of the emerging discipline:

Economic history studies the influence that economic factors have or have had on society, in general, or on any given country or region. And these main economic factors are-the situation, area, appearance, climate, population, products, industries and communications. (Antero 1905, I, v)

In contrast, Carneiro de Moura considered that the practice of economic history entailed other requirements, namely the knowledge provided by relevant statistical documentation, which was not sufficiently advanced in our country, in his opinion. As a result, he argued for a methodological renewal that was influenced by the German historical school's tenets:

History, based on social causality explained by environmental and social factors, illuminates the modern world in the light of the data studied and purified by science. (...) Portugal's economic history is the living and noteworthy testament of the laws that govern all human societies in the pursuit of wealth, and if our plan does not encompass the detailed theoretical exposition of these laws, we will nonetheless explain and verify the facts described (...)

The historical economic school despises a priori conceptions and observes economic phenomena by careful historical analysis. Unfortunately, in our case, we lack the statistical data and other analytical elements needed to accurately formulate economic laws. (Moura 1913, pp 8-19)

Carneiro de Moura presents economic history as a history based on the knowledge of how the factors of production evolved over time. His approach undoubtedly denotes modernity and an alignment with contemporary international contributions:

And other laws may be induced from our economic history. Through them, as we shall see, one observes the evolution of the three factors of production land, capital and man, or nature, capital and labor - first, beginning with the predominance of nature, followed by that of labor, and finally capital, towards a solidarity solution for the world economy, which re-establishes communal structures. (Moura 1913, p 19) 
A few years later, João Lúcio de Azevedo produced one of the most remarkable works of Portuguese economic historiography, giving rise to an interpretative model based on economic cycles associated with the temporary predominance of certain products (pepper, sugar, gold and diamonds). Notwithstanding the poor coherence or validity of the epochs (épocas) he considered, the clarity and pertinence of his approach remain unchallenged. Economic history proceeds to balance the costs and benefits that the country faces cyclically, as it moves between economic prosperity and decline:

The studies that comprise this volume adopt the materialist approach which, while not unique, is certainly indispensable in understanding history. Nations do not live on heroism alone, their beloved subject. For each nation there is a debt and credit account, as is there for individuals, which gives us insight into the nature of their prosperity, and the way in which the signs of decline manifest themselves early on, even for the greatest of empires.

With respect to Portugal, it will be interesting to inquire what price it paid for its past glory, and what effect it had on the country's general conditions. These pages are intended to provide those answers by attempting to outline the economic currents that shape our history. (Azevedo 1928, p 7)

Finally, the work of Francisco António Correia should be highlighted as we exhaust the set of authors who innovated methodologically in search of a discipline capable of providing consistent answers and explanations for the problems of modernization and blockages, improvement and backwardness. Indeed, it is in his book that we find a fuller systematization of an "Economic History of Portugal" based on successive cyclical movements, where the notion of continuity and path dependence on earlier states of evolution is maintained.

In order to understand well the national economy of our times, it is indispensable to study its evolution, all the forward and backward movements, and the causes that influenced the allocation and use of natural resources.

The economic organization of our country, as well as that of the rest of our social organization, may reflect the spirit of the reforms undertaken to improve it, but its structure, in fact, corresponds to a slow transition from previous modalities, which are linked to older ones, and where all are intimately interrelated (Correia 1929, v).

In conclusion, it is important to see a clear approach in these authors' work regarding the methodological orientations that economic history encompass in order to assert itself as an autonomous historiographical domain, notwithstanding their lack of originality in managing historical sources and processing relevant data. Moreover, it is an approach where economic history harbors the central concern of understanding the reasons that explain the country's backwardness, and the factors that drive its progress. This effort should be seen an academic complement to a greater civic purpose grounded in the wider public sphere, as seen in the reflections of academic and journalistic circles like, for example, the so-called Seara Nova generation. ${ }^{3}$

\footnotetext{
${ }^{3}$ Given the wider political and cultural scope of the Seara Nova journal, the discussion of its contents is beyond the scope of the present contribution. To be sure, this journal is an example of the modernity of Portuguese intellectual circles in the early 1920s, prior to the rise of the Estado Novo authoritarian regime. For more details on this topic, see Magalhães (2009).
} 


\section{Contributions from the History of Ideas}

As stated above, it is not always easy or even possible to distinguish the contributions that belong exclusively to the history of economic thought. In addition to the already mentioned contributions of J. Frederico Laranjo and Marnoco e Sousa, who sought to create a distinct field of inquiry, it is worth noting the multiple contributions that comprise the immense written heritage of Moses B. Amzalak. This heritage includes a very significant number of reading notes, bio-bibliographical sketches, excerpts from transcripts, new editions of out-of-print works and unpublished works. Amzalak is worthy of our attention due to his exhaustive survey of printed sources of great relevance for the study of the history of Portuguese economic thought. His contribution does not stand out either due to importance of his analytic commentary or due to the brilliance of his critical analysis. Instead, Amzalak surpassed his readers' expectations by drawing their attention to the way that the various generations of Portuguese economists contributed to an original reflection on economic problems, at the theoretical, doctrinal and political levels, or otherwise adapted the reflections of foreign authors to a domestic audience.

His style moves between the apology or glorification of Portuguese authors' originality, as well as those of Portuguese ascendency (Amzalak 1934 among many other titles), and also the organization of concise bio-bibliographical information on the authors that he read, transcribed and edited (Amzalak 1928 to cite only the most significant collection of his writings). In both instances, Amzalak was not concerned with distancing himself from the published authors and texts and was perhaps only enthused by the news that he brought to his readers. Notwithstanding his hermeneutic limitations, he nonetheless contributed to normalizing and stabilizing the manner in which the evolution of economic thought was recorded, in order to then become available as a tool for the most demanding craft of the historians who were to subsequently follow in his pioneering steps.

Another important contribution was that of António Sérgio who relied on the writings of the seventeenth century's most representative authors, such as Luís Mendes de Vasconcelos, Manuel Severim de Faria and Duarte Ribeiro de Macedo. In his approach, António Sérgio sought to construct an argumentative strategy around the great national designs, the great options imposed on the country on a permanent basis as opposed to a given moment in time (Sérgio 1924). In his eyes, Portugal faced the challenge of constantly choosing between "fixation or transport policies," the threats of decline and desire for a "Risorgimento," and the inevitability of the "crisis of intelligence" and the need for "corrective mind-sets." This was another way of looking at the factors of progress and the reasons for economic backwardness, in a framework shaped by the pessimistic tradition that was very much inspired by Oliveira Martins's intellectual legacy.

On a very different register, José Calvet de Magalhães would later provide an interpretative sequence for many of the authors briefly discussed by Amzalak and António Sérgio. This was undertaken with reference to a period that encompassed the economic literature from the medieval and mercantilist eras. Specifically, he enriched 
these two Portuguese authors' discussions by broadening the scope of their writings to include international comparative approaches (Magalhães 1967).

\section{The Consolidation of a Disciplinary Field}

Among the authors who sought to pay systematic attention to the history of economic doctrines and theories in Portugal, Armando Castro occupies an undisputed place, especially considering the final phase of his career. He was responsible for establishing a coherent interpretative model, inspired by Marxist methodology, that considered the legitimizing function of conceptual constructions and doctrinal elaborations associated with the development of the capitalist economy's material basis, at the social and political levels. ${ }^{4}$

The same Marxist programmatic orientation is to be found in his approach to the interpretation of Portuguese economic history, as is clear in the following excerpt:

We think it is preferable to approach our economic history in such a way to easily understand the fundamental aspects of economic laws, and evolution of social relations related to production. Historical-economic studies of this kind are of real scientific and cultural interest, as the mere compilation of retrospective data, which interests those who study these questions, is unable to provide a causal explanation for the facts; in order to attain this scope of analysis, it is necessary to identify the social classes in action, the type of relations existing between them, and to examine the repercussions of the material productive forces' development on production's social relations. (Castro 1947, pp 9-10)

Vitorino Magalhães Godinho also cultivated a faithful commitment to a coherent model of interpretation that yielded many and fruitful empirical research results. Undoubtedly, he was one of the authors who best and most contributed to the development of an interpretative canon of Portuguese economic and social history. ${ }^{5}$

Without ever losing his passion for archives, respect for sources and concern for taking great care of documents, the history that Vitorino Magalhães Godinho pursued, in keeping with the practices of the Annales French school, is particularly demanding in terms of the theoretical construction process and the necessary conceptual elaboration, which allows for a better understanding of the succession of events. He also never yielded to the acritical positivism that characterized the work of many historians of his generation, given that he did not see economic and social history simply as narrative of sequential facts that had been positively assessed and linked together without any causal explanation (Godinho 1947). The events that have been painstakingly reported and reproduced from secure and trustworthy sources must be seen within a long-term perspective. They require, above all else, an interpretative effort that makes use of rational understanding based either on the construction

\footnotetext{
${ }^{4}$ Given the chronological scope being considered here, the texts published by Armando Castro after 1974 are not discussed. For the discussion of these and other later contributions covering the most recent historiography of Portuguese economic thought, see Cardoso (1991).

${ }^{5}$ A more detailed approach to Magalhães Godinho's innovative contributions in this field is provided in Cardoso (2011), which is also the source for the paragraphs that follow.
} 
of ideal types (in the best Weberian tradition) or on problem formulations that then require the historian to provide both explanations and solutions. Two examples taken from his work help us to understand his positioning and proximity to the spirit of the Annales school on this matter.

The first example relates to the concept of a "historical-geographical complex" which he himself invented, and through which he sought to discern the linkages between spatial or territorial structures located in space but whose time possessed both rhythms and cadences, thus capturing both short and long dynamics, i.e., spaces that change with the rhythm of history itself. In this complex, actors and institutions come to interact (with their own directions but joint dynamics), economic, social and political relationships are established along different spatial scales (local, regional, national, worldwide), and cultural and ritual practices are defined, thus affording specificity to the historical realities being analyzed (Godinho 1966).

His study of trading networks and commercial fleets in the Indian and South Atlantic Oceans, within the broader perspective of the study of global markets, allowed Magalhães Godinho to develop the heuristic validity of this concept. In doing so, he intertwined the following elements: the dialectic relations and tensions between space and time, conjuncture and structure, short and long term, micro- and macro-analysis, and facts and ideas. More importantly, this concept allowed him to explore the paths that lead to a better historical understanding of complex social phenomena.

In this sense, and to take one of his more preferred themes as an example, merchant fleets are, above all else, the collection of vessels that comprise them. In another sense, however, they are also the cargoes that the vessels transport, the men that build, equip and sail in these vessels, the institutions and powers that determine and finance the voyages and trade they undertake, the science that allows for maritime navigation, the risks and insurance schemes that make the sailing feasible, the markets that allow for the free movement of goods transported and the currencies used to transact them, the trading bills of exchange that circulate, the myths facing the vessels' crews as well as the purpose and vision motivating them.

The second example is related to the concept of Portugal as a "blocked society," which Magalhães Godinho developed in one of his more remarkable (and more controversial) essays. He used this notion to coherently explore the vicissitudes of blockages at different moments in Portuguese history, which illustrate or provide a pretext for studying the problems of backwardness, dependence and decadence, waste and misuse of resources, mind-sets and cultural aspects that are not much given to innovation and the advancement of knowledge (Godinho 1971). This approach represents a new encounter with the works of historians Oliveira Martins and António Sérgio, as discussed above, and thus provides clear evidence of the weight of this tradition in Portuguese economic historiography.

For a perspective that is less attached to the need for paradigm changes, the studies and essays written by Virginia Rau during the 1940s, 1950s and 1960s are worth mentioning. Her contributions cover themes pertaining to the ancient regime's economic and social history (collected in Rau 1984). The works on Portuguese and foreign merchants, trading places, bankers, shipbuilding, foreign trade relations, 
as well as on the economic thought of mercantilist era writers (sixteenth to eighteenth centuries), reveal an extreme caution when it comes to analyzing sources and explaining their relevance to the study of historical problems. They also reveal a fundamental concern with the framing of facts and people, and a keen perception regarding the flow of goods, capital and currencies, as well as the analysis of technical conditions, contractual regimes, and labor and power relations.

One last author deserving our attention in this brief assessment of Portuguese economic historiography prior to 1974 is Jorge Borges de Macedo. ${ }^{6}$ His works are mainly motivated by the need to contradict the subaltern interpretations of economic ideas and practices, as espoused by numerous Portuguese authors regarded as being representative of a certain national elite. Seeking to chart new paths to better understand the modernization and blockage processes of the Portuguese economy, Borges de Macedo focused instead on diplomatic and political conjunctures and external competitive factors that could affect the development of economic sectors, especially industry. In doing so, he produced groundbreaking studies in which he demonstrated a skillful handling and problematization of hitherto untapped archival sources. His studies have contributed decisively to renewing the interpretative legacies of the economic reality during the Marquis of Pombal's rule, the history of industry in the eighteenth century, the Methuen Treaty (1703) and the economic consequences of the Continental Blockade in the early nineteenth century.

However, his most solid contribution to the understanding of Portuguese development problems was his interpretation of the history of industrial equipment, banking and port activities, as well as the economic and political strategies defined by sovereign decision makers in the eighteenth century in the face of a contingent framework of complex international relations (Borges de Macedo 1963). In this regard, his historical inquiry offers a variety of readings about Portuguese economic and political thought in the eighteenth century, which is always seen from the perspective of innovative application of principles that may be used to interpret economic and social reality, while simultaneously helping to define strategies and policies with a view to their reform and/or development.

Without exhausting or foreshadowing the development of other categorizations that might help us to understand the essential features of the economic doctrines and policies that prevailed in Portugal throughout the eighteenth century, I believe it is pertinent to suggest three central ways of organizing economic discourse during this period, which deliberately takes the reflections provided by Jorge Borges de Macedo in his essays as our starting point.

\footnotetext{
${ }^{6}$ For an overview of Borges de Macedo's role in the renewal of economic history and the history of economic thought, see Cardoso (2013), from which the following paragraphs on are adapted. By including this analysis, I wish to pay tribute both to Jorge Borges de Macedo and to his son, Jorge Braga de Macedo, to whom I dedicate the present contribution. In addition, by attempting to replicate a style that is so typical and so unique in Jorge (the son) - for whom the nature of academic texts does not rule out the inclusion of personal remembrances and emotions-when evoking the work of Jorge (the father), I am also following the steps of the father's tradition "Saber Continuar" (knowing how to go on), as explained in Braga de Macedo et al. (2009).
} 
The first of these ways relates to the definition of the direction that economic policies should follow. Such a view applies specifically to the study of mercantilism which, for Borges de Macedo, "is not a systematic theory, but rather a series of useful items of knowledge that do not form a chain leading to a systematic interpretative coordination of the whole economic reality" (Borges de Macedo 1966a). He therefore sought to identify and highlight a variety of influences, and a range of strategic options converging in such a way so as to achieve an objective or a central purpose that, in effect, strengthened the state's economic performance.

The second path that faithfully portrays another dimension of Portuguese economic discourse in the last quarter of the eighteenth century may be expressed as follows: getting to know the kingdom better in order to change it. Once again, we rediscover the insightful attention that Borges de Macedo paid to a remarkable group of authors who acted either independently or under the institutional auspices of the Academy of Sciences of Lisbon and other learned institutions during the governments of Dona Maria I and the Prince Regent Dom João. The following citation summarizes clearly this situation:

The end of the eighteenth century was overcome by a genuine anxiety for analysis and creativity that led to the formation of the richest, most varied and most fertile Portuguese technological bibliography, with the appearance of books ranging from the debate about metropolitan and overseas agrarian problems to studies of accountancy, mechanics, ballistics and medicine. The problems were studied from a practical point of view and were clearly adapted to the national realities. (Borges de Macedo 1966b, pp 131-32)

Such "anxiety for analysis and creativity" resulted in the definition of a strategy making the fullest possible use of available natural and human resources, which in turn presupposed the undertaking of a stringent diagnosis of both the favorable conditions and the limits that were imposed on economic activity. Science and technology, together with the knowledge of the natural and social world, were instruments placed at the service of economic development. However, it was also important to understand that agents had to be free to act as they wished if human activity were to be effective in the economic field, and that principles and measures favoring the extension and enhancement of mercantile relations should also be pursued.

Finally, and in a similar vein, the third path may be summarized as: managing the economic conjuncture in order to develop the country. Jorge Borges de Macedo's works also elucidate us about the need for pragmatism in the face of an external political alignment that imposed negotiated trajectories, as well as a cautious and prudent mind-set needed to deal with domestic financial difficulties. In this regard, the testimony provided by Dom Rodrigo de Sousa Coutinho's activity between 1796 and 1803, in the exercise of his governmental responsibilities, as well as in the programmatic texts that he bequeathed to us, merits a special mention. In fact, this explanatory context enables us to understand the extent of economic and financial reforms designed to guarantee an indispensable political and institutional stability. The correction of past mistakes due to the uncontrolled issue of fiat money, plans for the creation of a banking institution, financial restructuring programs and colonial administration reforms were some of the matters warranting Dom Rodrigo de Sousa Coutinho's full attention as part of his public mission. Moreover, he showed to himself to possess a sense of proportion and priority in facing the international conjuncture 
where Portugal's fate was at stake. This is the hallmark of great statesmen, where it was important to manage affairs but without jeopardizing the future of the country.

\section{Epilogue}

Magalhães Godinho and Borges de Macedo provide relevant inputs into the advancement of innovative approaches on economic history and history of economic ideas, especially regarding the study of historical factors and conditions needed for Portugal's economic growth and development. In both cases, their point of departure, and motivation, is grounded in their concern with history. As such, they were able to extend and challenge a historiographical tradition going back to the nineteenthcentury works of Alexandre Herculano and Oliveira Martins, which was prolonged into the early twentieth century by João Lúcio de Azevedo and Francisco António Correia.

However, a different stream of thought associated with a reflection on development issues emerged toward the end of the period being considered here. It was led by economists and sociologists with strong ties to the Latin American structuralist school, which encompassed the work produced for the United Nations Special Commission for Latin America (CEPAL_Comisión Económica para América Latina). The CEPAL writings and action programs had their followers in Portugal, both in the renewed environment of teaching economics at the Institute of Economic and Financial Sciences (ISCEF-Instituto Superior de Ciências Económicas e Financeiras) and in the most modest circle of social scientists collaborating at the Social Research Office (GIS_Gabinete de Investigações Sociais) together with its Análise Social academic journal. It was, after all, a current of economic and social thought that took into account the importance of history in understanding the conditions conducive to modernization and development, which demanded from politicians the initiative to favor the indispensable conditions needed to break the ties of dependency and intra-country asymmetrical relations (cf. Nunes 1968).

This interpretative trend would remain active well beyond this contribution's temporal scope, notwithstanding the cliometric orientations of a new economic history committed more to providing hypotheses and quantitative-driven essays of relevance to the functioning of the Portuguese economy than to reactivating the specter of economic backwardness and decline. While these times are interesting given their critical conjunctures associated with processes of historiographical renewal, they clearly warrant a future contribution that goes beyond the present one.

\section{References}

Amzalak MB (1928) Do estudo e da evolução das doutrinas económicas em Portugal. Oficinas do Museu Comercial, Lisboa 
Amzalak MB (1934) Trois précurseurs portugais. Sirey, Paris

Antero A (1905) História económica (6 vols). Tipografia A. J, Silva Teixeira, Porto

Azevedo JL (1928) Épocas de Portugal económico. Livraria Clássica Editora, Lisboa

Borges de Macedo J (1963) Problemas de história da indústria portuguesa no século XVIII. Associação Industrial Portuguesa, Lisboa

Borges de Macedo J (1966) Vias de expressão da cultura e da sociedade portuguesas nos séculos XVII e XVIII. Boletim da Academia Internacional da Cultura Portuguesa 1:121-133

Borges de Macedo J (1966a). Mercantilismo. In: Serrão J (ed) Dicionário de história de Portugal. Iniciativas Editoriais, Lisboa

Braga de Macedo J et al (eds) (2009) Nove ensaios na tradição de Jorge Borges de Macedo. Tribuna, Lisboa

Cardoso JL (1991) A recente historiografia do pensamento económico. Ler História 21:146-153

Cardoso JL (2011) Vitorino Magalhães Godinho and the Annales school: history as a way of thinking. E-J Portuguese History 9(2)

Cardoso JL (2013) Jorge Borges de Macedo: problems of the history of Portuguese economic and political Thought in the eighteenth-century. E-J Portuguese History 11(2)

Cardoso JL (2017) Modernização e bloqueios. Problemas do desenvolvimento económico na memória histórica. In: Matos SC, João MI (eds) Historiografia e res publica nos dois últimos séculos. Centro de História da Universidade de Lisboa, Lisboa, pp 163-182

Castro A (1947) Introdução ao estudo da economia portuguesa (fim do século XVIII a princípios do século XIX). Edições Cosmos, Lisboa

Correia FA (1929) História económica de Portugal. Empresa Nacional de Publicidade, Lisboa

Cortesão J (1930) Os factores democráticos na formação de Portugal. New edition s.n. (1964). Portugália, Lisboa

Godinho VM (1947) História económica e social da expansão portuguesa. Terra Editora, Lisboa

Godinho VM (1966) Complexo histórico-geográfico. In: Serrão J (ed) Dicionário de história de Portugal. Iniciativas Editoriais, Lisboa

Godinho VM (1971) A estrutura da antiga sociedade portuguesa. Arcádia, Lisboa

Herculano A (1873) Opúsculos. Viúva Bertrand, Lisboa

Laranjo JF (1891) Princípios de economia política. Imprensa da Universidade, Coimbra

Laranjo JF (1881-1884) Economistas portugueses. New edition s.n. (1976). Guimarães editores, Lisboa

Magalhães JC (1967) História do pensamento económico português. Da Idade Média ao mercantilismo. Imprensa da Universidade, Coimbra

Magalhães JR (2009) Oração de sapiência proferida na abertura solene do ano lectivo. Notas Económicas 30:41-62

Martins JPO (1872) Teoria do socialismo. Evolução política e económica das sociedades da Europa, Guimarães Editores, Lisboa

Martins JPO (1883) O regime das riquezas (elementos de crematística). Livraria Bertrand, Lisboa

Martins JPO (1885) Política e Economia Nacional. Guimarães Editores, Lisboa

Moura C (1913) História económica de Portugal. Tipografia do Anuário Comercial, Lisboa

Nunes AS (1968) Sociologia e ideologia do desenvolvimento. Estudos e ensaios, Moraes Editores, Lisboa

Pereira JME (1979) A indústria portuguesa: subsídios para a sua história, 1897 e 1900. Guimarães Editores, Lisboa

Rau V (1984) Estudos sobre história económica e social do antigo regime. Editorial Presença, Lisboa

Sampaio A (1923) Estudos históricos e económicos, vol I. Livraria Chardron, Porto

Sérgio A (1924) Antologia de economistas portugueses: Séc XVII. Biblioteca Nacional, Lisboa

Sousa JFM (1910) Ciência económica. Imprensa da Universidade, Coimbra

Teles B (1901) Estudos históricos e económicos. Livraria Chardron, Porto 